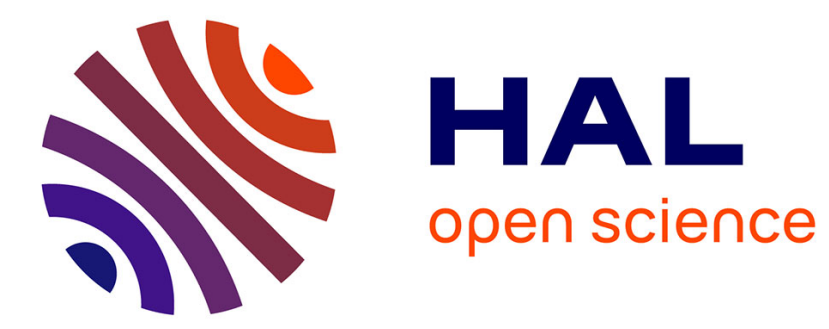

\title{
Imaginaries of Europe
}

Gail Lewis

\section{- To cite this version:}

Gail Lewis. Imaginaries of Europe. European Journal of Women's Studies, 2006, 13 (2), pp.87-102. $10.1177 / 1350506806062749$. hal-00571270

\section{HAL Id: hal-00571270 https://hal.science/hal-00571270}

Submitted on 1 Mar 2011

HAL is a multi-disciplinary open access archive for the deposit and dissemination of scientific research documents, whether they are published or not. The documents may come from teaching and research institutions in France or abroad, or from public or private research centers.
L'archive ouverte pluridisciplinaire HAL, est destinée au dépôt et à la diffusion de documents scientifiques de niveau recherche, publiés ou non, émanant des établissements d'enseignement et de recherche français ou étrangers, des laboratoires publics ou privés. 


\title{
Imaginaries of Europe
}

\section{Technologies of Gender, Economies of Power}

\author{
Gail Lewis
}

UNIVERSITY OF LANCASTER

\begin{abstract}
This article explores some of the ways in which ideas about and attempts to construct a European identity and sense of belonging inscribe an imaginary of Europe that is exclusionary and elitist. It suggests that the symbolic figure of 'the immigrant woman' is a container category that simultaneously signifies the non-European and tests and destabilizes claims to Europe's essential characteristics. It also argues that traces of this imaginary of Europe can be found in feminist scholarship on global care chains and that the spatial category of the domestic' is the invisible seam that ties this scholarship to the hegemonic imaginary of Europe.
\end{abstract}

KEY WORDS 'the domestic' $\bullet$ Europe $\bullet$ global care chains $\bullet$ humanity imaginary $\bullet$ 'the immigrant woman' $\bullet$ universality

Conscious that Europe is a continent that has brought forth civilisation; that its inhabitants, arriving in successive waves since the first ages of mankind, have gradually developed the values underlying humanism: equality of persons, freedom, respect for reason, Drawing inspiration from the cultural, religious and humanist inheritance of Europe, the values of which, still present in its heritage, have embedded within the life of society its perception of the central role of the human person and his or her inviolable and inalienable rights, and respect for law,

Believing that reunited Europe intends to continue along this path of civilisation ... for the good of all its inhabitants, ... that it wishes to remain a continent open to culture, learning and social progress. (Preamble to the Treaty Establishing a Constitution for Europe, Commission of the European Union, 2003) 


\section{INTRODUCTION}

The convergence of the political and pedagogical agenda of new social movements with the intellectual agenda established by poststructuralist theory has led to a concern to foreground and explore the social production of difference, the livedness of the particular, the specificity of the 'minoritarian'. As part of a politics that seeks to challenge and destabilize multiple and intersecting structures of power, the importance of contemporary concerns about the dynamics of difference cannot be overstated. Yet to recognize the importance of an ever deepening understanding of the complexities of multiplicity and intersectionality should not preclude a parallel concern to analyse how discourses of the universal continue to operate as the constitutive ground for these geometries of power and structures of inequality. Indeed, these structures of power and inequality are inscribed in the relation between the universal and the particular, as feminist and other fields of scholarship have so ably established. In this context, this article explores some of the ways in which the attempt by the European Union (EU) to construct a common European identity, grounded in claims that Europe is the cradle of civilization, inscribes an imaginary of Europe that is exclusionary and elitist. Balibar (1991: 62) has noted that one consequence of the idea of Europe as the land of 'modern' nation-states and 'civilization' is that racism acquires meaning beyond the nation-state at the level of the universal. It is aspects of this process that I analyse here.

My focus is on the symbolic representation of a category called 'the immigrant woman'. I argue that in the contemporary moment this category is central to the hegemonic social imaginary of Europe and the European. Of course, 'Europe' and 'the European' are also symbolic categories in much the same way as that of 'the immigrant woman'. As such, these symbolic categories are mutually imbricated and craft a field of cultural meanings that produces its own emergent logic. This logic in its turn defines the discursive limits of civilization and the relation of differentiated human groupings to that civilization. This is a logic that has its roots in colonial discourse, as postcolonial theory has shown, and which continues to have social effectivity. However, while this logic contributes to the marking out of a variety of racialized and ethnicized subject positions, the categories I discuss are not commensurate with actually existing migrants and the European-born descendants of migrants (who continue to be named as immigrants) who are swept up in the hierarchies of humanity that the hegemonic imaginary of Europe symbolically produces. The logic produced by this symbolic field acts more as a kind of Saidian (Said, 1993) 'consolidated vision' in which that which is taken as essentially 'other' to Europe and the European is historically continuous and 'known'. Thus the article speaks in a generalized 
way in order to draw out the contours of an increasingly Manichean symbolic universe in which 'Europe' re-presents and positions itself as a universal standard of humanity.

In the domains of institutional, juridical and everyday social practice there are, of course, multiple distinctions of legal status, of social condition and forms of social interaction, among actors who inhabit an increasingly complex social field within and beyond the constituencies summoned up under the signs 'native' and 'migrant'. Similarly, there are multiple and shifting processes of identification and dis-identification among old and new groups of migrants, Europeans from west and east, north and south, Protestant and Catholic.

But, and this is the core of my argument, in the context of post-9/11 (US), post-9/3 (Spain) and post-7/7 (Britain), the symbolic struggle (alongside the apparently more material arena of legal control of immigration and social control of minorities) over what it means to be European, where Europe begins and ends, who can stand for and be of Europe and the European has assumed a far-reaching intensity. In this context, there is a resort among many who claim to stand in Europe's image to a symbolic field in which that which is 'essentially' European is claimed as the originary site of progress and morality, as is evident from the declaration in the EU policy document cited in the epigram with which I opened and which is echoed in the words of 'Nina', an employer of domestic workers, cited later. While what may be at stake in claims such as these is a desire for a degree of ontological security and certainty in times when such security seems anything but certain, the constitution of this symbolic universe obscures the actually existing complexity that is Europe's historical and contemporary reality. In this fantasy and the erasures it effects, the figure of 'the immigrant woman' acts as a container category for all that is not Europe/European even while this figure is the symbolic site upon which Europe makes claim to its status as the cradle of humanity and civilization.

Unfolding as a set of contrapuntal moves and occasionally referring to artefacts from popular culture, the argument works at the level of the general to analyse and challenge the imaginary of Europe circulating in policy and academic fields.

\section{IMAGINARIES OF EUROPE}

In 1972, the Council of Europe adopted Beethoven's 'Ode to Joy' ${ }^{1}$ as the anthem of the EEC, since when it has retained this function, surviving an evolving and ever widening geographical spread of something called 'Europe'. 'Ode to Joy' has retained its status as the European anthem as a way of symbolizing the creation of a new constituency of solidarity and 
belonging. While running in parallel with the national anthems of individual member states, this music 'celebrates the values the [member states] share and their unity in diversity'. ${ }^{2}$ Interestingly and despite claiming a correspondence between the 'Ode' and 'the ideals of freedom, peace and solidarity for which Europe stands', ${ }^{3}$ the words to the 'Ode' have been dropped from the anthem version. These words, penned in 1785 by Friedrich von Schiller, are a call to 'brotherhood', mutual friendship, union in marriage and humility before (the Christian) god. The 'Ode' as anthem is symbolic of Europe and its hegemonic imaginary in ways unanticipated by the heads of state who continually choose it to represent them, their peoples and their modes of governance. For in eliminating the words, Europe's governors both avoid some of its contemporary limitations and occlude those aspects of Europe's historical and current practices that bespeak the other side of freedom, peace and solidarity.

In ways echoing the configuration of global connections some 500 years earlier, 1992 represented a pivotal spatio-temporal moment in that it inaugurated a particular (if unstable) set of relations between Europe, as EU, and its others. Developing from the provision for the free movement of goods, capital, services and labour within the area covered by the provisions of the Single European Act of 1987, the Maastricht Treaty established the category of 'Citizen of the European Union'. This citizenship does not replace citizenship of individual nation-states - indeed EU citizenship is dependent upon national citizenship. Maastricht and its subsequent amendments and extensions in Amsterdam and other intergovernmental agreements also commit member states to seek greater harmonization across a number of fields of activity, including common foreign and security policy and police and judicial cooperation in criminal matters. The EU is tied together through a multistranded institutional nexus and includes its reiterated claims to be true to the characteristics that make Europe a place that 'the world looks to . . . for principled leadership, and our citizens look to ... for effective European action. Action guided by our shared European values and that strengthens our essential European identity' (Commission of the European Communities, 2000: 3).

It is worth noting that this idea of an 'essential European identity' premised upon something called 'shared European values' is a significant criterion by which states wishing to accede to the Union are judged. Thus in 2002 , when it was agreed that 15 would become 25 , entry was in part facilitated on the basis that the accession states met a number of criteria political, social, economic, institutional, judicial and cultural - that were adjudged sufficiently, and emblematically, European. Of course, 'wanna be' Turkey failed.

If the 'Europe' signalled by the spokespeople and symbols of the EU is one that connotes a set of characteristics, values and institutional frames 
and practices, Europe does not, however, denote a clear geographical entity or a singular set of cultural or political institutions. For example, there is the Europe that comprises the nation-states of the EU - though even this is internally divided by belonging to Euroland, or not, to the Schengen travel area, or the Western Union and/or NATO. Then there is the spatially configured Europe comprised by the nation-states that lie on the land mass thought of as Europe but lie outside the EU. And, of course, there is the Europe of the Eurovision Song Contest! And what of those départements of France that lie within the Caribbean or Indian Ocean - are they too 'Europe'? And the Sami peoples of northern Scandinavia and Finland - who would count them as emblematically European?

The existence of these multiple Europes indicates the constructed character of 'Europe' and 'European-ness' and also highlights the instabilities of attempts to define Europe as ontological fact and singular entity. This instability and constructedness suggests that it is more appropriate to think of 'Europe' as an idea that privileges a particular spatial configuration and also attempts to claim a specific - and superior - way of being human as its especial characteristic. In this context, struggles over the meanings of 'Europe' become significant for feminists, urging consideration of the content and effects of the idea of Europe.

Europe is, however, both limited to and more than an idea. It is an idea in the sense that it is a symbolic construct organizing individual and collective imaginings as to Europe's peoples, behaviours, morality, worldview, institutional forms and geographical borders. In this sense, it is a zone formed through active imaginings that construct belongings, specificity and the limits of both. But this zone is also made material by the actions of states that transform geological and cognitive surfaces into boundaries that physically and legally demarcate its borders and impose the limits on who might cross and/or come to represent these borders and on what terms.

What this suggests is that the idea of Europe comprises a number of strands that combine to delineate the specificity - or difference - of the European. Among those strands are two that have relevance for my argument. The first marks a spatio-temporal register. It is the notion that Europe is an 'old' culture, whose roots are embedded in centuries of tradition and make for an ancient 'western' civilization, which despite shifts in its geographical centre of gravity and bleak moments of aberration, is understood to have stood the test of time and bequeathed an indelible and superior moral, cultural and political legacy on Europe and Europeans. Second is the idea that 'Europe', homogenized above the specificities of individual nation-states and national cultures, is distinguished by its core principles of freedom, of family and private life and respect for and promotion of tolerance. As Article 6 of the Declaration of Fundamental Rights and Freedoms states 'Everyone shall have the right 
to respect and protection of their identity; respect for privacy and family life, reputation, the home'.

There are, of course, many examples where these ideals are far from institutional or individual practice and often contradicted in law and custom, including prevention of family reunification, the systematic forced sterilization of Roma women and other human rights violations.

The invocation of the family silently, yet powerfully, summons up gender and generational relations, drawing attention to the interconnection between a certain gender and familial order and the idea of Europe. Indeed, such an interconnection has a long history. One powerful example can be found in Persian Letters (1721) written by key Enlightenment figure Montesquieu, in which he discusses both contemporary questions of politics and society and the differences between the East and the West. The letters are staged between two Persian lords, Usbek and Rica, who are travelling across Persia, Turkey and Italy to France and included in the letters are some concerning Roxanne, Usbek's favoured wife, and the breakdown of order in the harem (letters 147-161) where, among other things, Roxanne has been found with another lover. From afar, Usbek tries to re-establish order. For Roxanne, in a kind of prefigurative film noir gesture, the way out is suicide but not before she has protested her right to freedom and autonomy of the person. As Michael Mosher (1994) has pointed out, for Montesquieu, claims about the specificity of Europe - or more precisely about European potential - rested upon the extent to which women, and by metaphoric extension all weaker parties in a social system, 'discover a route into the public life' (Mosher, 1994: 26) and thus escape the despotism of men and a despotic patriarchal system. This potential for freedom lies immanent in Europe, especially its Republican states, but is not a potential that the 'East' (over 'there' or within Europe itself) can achieve because, in the 'East', communication between the dominant and subordinate is not possible. Communication is impossible because of the formal separation and hierarchicalized power of male and female (elite and subaltern) spaces, a separation represented by the harem. This ethno-spatialization of emancipatory possibility is shown to us (Mosher argues) in the multicultural ambiguity of Montesquieu's heroine 'Roxanne'. 'Roxanne was simultaneously a Persian wife and a French citizen. The Persian cannot free herself, ... but the French citizen and woman might be more fortunate' (Mosher, 1994: 28).

What is fascinating about this is the way that it prefigures current concerns and issues that saturate contemporary politics. Questions of visibility; the potential for gender freedom; which variation of human social organization can claim moral and political superiority - are all terrain with which we are familiar, especially in these Islamophobic times.

Thus the claim to European specificity is an idea that translates into a claim of sociopolitical advancement and superiority that rests upon an 
image of women's freedom and a particular kind of gender order between women and men. It is a symbolism that positions Europe and the European as the standard of humanity and closes down questions as to whose identity, autonomy, family and privacy are to be respected, at whose cost and with what consequences for Europe's potential for an economy of gender equality. In doing so, it throws back the issue of visibility, not only to ask who and what is visible but who sees what.

\section{TECHNOLOGIES OF GENDER}

I use these ideas to explore how they might help us to think about the contemporary organization of gender relations across differentiated femininities. I use two interconnected fields to do so. First, the figure of 'the immigrant woman' (today symbolically incarnated in her Muslim variation), since it is this figure who has been taken to embody struggles over the meaning and effects of visibility. The figure of 'the immigrant woman' is a general but flexible category that can be used, concertina fashion, by states, politicians, policy-makers, professionals and others in a contingent and tactical way to enclose an expanding or narrowing range of social constituencies depending upon context and agenda. Second, I examine the intersecting and unequal femininities produced through the organization of gender relations around global care chains. In doing so, I draw on some of the excellent work carried out by feminist scholars and activists in different parts of Europe. Detailed empirical studies such as those carried out by Bridget Anderson (2000, 2003), Kofman et al. (2000), Parrenas (2001) and Lutz (2002), and campaigning organizations of migrant women working in domestic service such as Kalyaan in the UK, to name a few, have all identified some of the conditions under which these women labour. My argument here is twofold. First, that just as the long-standing and continually reproduced imaginary of Europe is constitutive of a certain fantasy of Europe's gender order and its apparent transparency and equality, so this legacy of representation in part shapes the relations between different femininities and the women who inhabit them. Second, I want to conceptualize the relations between women inhabiting different femininities and differentiated by ethnicity and class as themselves gender relations. Thus, in addition to thinking of gender relations as those forms of social organization constituted around sexual difference and the binary divide between men/women or masculinities/ femininities, I am proposing an additional dimension. This is that we conceive gender as expressive of and constituted by the range of womanhoods that exist in one side of the binary. 
Destabilizing the European Imaginary I: The 'Immigrant Woman'

Across Europe, there are numerous sources of challenge (including campaigning organizations and artists) to the notion of the abject ethnically 'different' woman. Such challenges re-present the 'other' woman as a subject whose visibility and voice defy the crude stereotypes that circulate in the discursive space of 'the European'. The non-alignment between self-defined womanhoods of the 'other' woman and the figure of 'the immigrant woman' inscribed in the imaginary of Europe exposes the limits of liberal tolerance precisely because her visibility is to be erased. Such erasure can be achieved through a number of strategies: through, for example, enforced sterilization or immigration and asylum controls, including policies about family reunification. So too, those hegemonic politics of representation that preclude the entry of subaltern practices of representation into the field of cultural discourse, or at the very best, reassign such subaltern practices as 'other' and minority.

Significantly, the site of struggles over the visibility of the 'immigrant woman' and the meanings ascribed to her is often her body. This might be in relation to how she adorns her body, how she raises the children she bears, or expresses her sexuality - but the tension between tolerance and visibility runs through them all. On the one hand, her visibility can be on her own terms in that her bodily adornment is such that it displays both her difference - and her claim to this difference. On the other hand, hegemonic inscriptions of her might be such as to homogenize her around an axis of Eurocentric heteronormativity in which an identity such as 'Muslim/Queer' can only be greeted as oxymoronic. Thus, the figure of 'the immigrant woman' simultaneously raises a question about how much difference can be respected, and exposes the strategies used to deny her visibility in all her complexity and variety.

This tension between visibility and tolerance also runs through ideals and strategies of assimilation into what have become increasingly referred to as 'core national values' in a number of European states (see Lewis and Neal, 2005). While the acceptance of migrants has been taken as a hallmark of Europe's democracy and tolerance, when refracted through the ideal of visibility, assimilation illustrates well the ambivalences with which 'the immigrant woman' is regarded. At once a means by which to 'liberate' the woman caught in the clutches of a despotic familial and/or state culture, assimilation is also a mechanism that, if successful, undermines claims to respect for and tolerance of difference. Examples of the limits of tolerance are l'affaire $d u$ foulard that first became a cause of official and popular concern in France in the late 1980s and culminated in the introduction of a law in 2004 outlawing the wearing of overt religious insignia in public places such as schools.

Interestingly, l'affaire $d u$ foulard provides an illustration of the breadth 
and tenacity of the idea of Europe. In an open letter to Harlem Desir, then president of SOS Racisme, Julia Kristeva (1993) provides a case in point whereby she draws upon Montesquieu's L'Espris des Lois as a way of reminding school children of the hierarchy of loyalties that would ensure integration without domination.

If I would know something which would aid me, and which would be harmful to my family, I would reject it from my soul. If I knew of something which would be useful to my family and which would not be to my country, I would try to forget it. If I knew something which would be useful to my country, and which would be harmful to Europe, or which would be useful to Europe and harmful to humanity, I would regard it as a crime. (Kristeva, 1993: 63)

As Norma Claire Moruzzi (1994: 665) notes, while some might see a sacrifice of national interests and identities to that of Europe and Europeanness as indicative of tolerance and generosity of spirit, the cost for North African Arab immigrants (and their children) may be precisely the erasure or delegitimation of their familial, diasporic, non-European identities and global connections.

All this makes for the undecidable quality of the symbolic immigrant woman. Is she to be divested of her visibility as an 'immigrant' woman by processes of assimilation, even if there is some element of coercion in such processes - in which case she is no longer the immigrant and the very test of European tolerance and democracy, her visibility, evaporates? Or is she to be 'allowed' to demonstrate her difference and (according to those bound in the dominant European imaginary) abjection and thus 'display' the contamination in 'our' midst - in which case Europe's civilizing mission is undermined? Either way, the figure of 'the immigrant woman' both bespells and exposes the limits of 'Europe'.

\section{Destabilizing the European Imaginary II: Domestic Workers}

Artefacts of Euro-American popular music and culture conjure up exactly what fantasies are protected when the 'underside' of Europe's imaginary gender economy and capacity for tolerance is subject to restricted vision. For example, the endless photographic evocations of domestic bliss published in magazines ranging from Marie Claire to Country Life. Yet this is a fantasy that is consistently challenged from within the very practices of domestic life by the presence - and visions - of those women upon whose labour it often depends.

In recent years, feminist scholars have developed a burgeoning literature on what Arlie Hochschild (2000) termed 'global care chains'. This work has added an extremely important dimension to our understanding of the operation and effects of processes of globalization, helping to lift 
analysis of the latter out of its masculinist and economistic stranglehold. It has also revealed just what is at stake for the vast numbers of women migrants around the world who leave to find employment in forms of care/service work around the world. Popular culture also offers us glimpses into this world as Nina Simone's rendition of the Brecht/Weil classic 'Pirate Jenny' (1964) chillingly conveys as she shows just what is at stake when the domestic workers' capacity to see is denied, what she sees is disavowed and her claims for social justice and citizenship delegitimized.

But how would any of this relate to imaginaries of Europe? The connection lies in the double meaning of the domestic as household (including this as the site of legitimate sexuality) and nation(al), both of which have roots in colonial discourse and practice. I want to begin to tease this out by starting with two quotations. One is contemporary and is part of an interview Bridget Anderson (2003) conducted with a woman in Greece, who had a long history of employing migrant domestic workers. The second is historical and is taken from Ann Laura Stoler's (2002) work on 'race' and the intimate in the colonial order.

\section{Extract 1:}

There is no feeling for what I offer. I'll give you an example of the last woman from Bulgaria ... I had a bright idea: 'She needs to see her friends'. Because I was tired of all the turnover, I gave her Sunday off ... Now, every morning, including Sundays, the girl wakes up, helps grandmother to the toilet and changes her Pamper ... Then goes, but she must be back before seven p.m. ... Then after all I do for her, the girl says every Sunday she would like to be back at midnight, and not to do any work - that is, not to change the Pamper in the morning. (Nina, Athens; cited in Anderson, 2003: 111)

\section{Extract 2:}

She would ... take me in her lap. The fragrance of her body and her clothes, of her sarung especially. I must have intensively inhaled, a sort of pre-erotic! She caressed me by nestling me against her ... Now I still recollect this fragrance, because smells can remind me of it! .. . such was my relationship to her. (Robert Nieuwenhuys, 1995; cited in Stoler, 2002: 164)

Despite their gendered registers and different concerns, locations and times, these two quotes are interesting precisely because it is on the terrain of the domestic (in its double sense) that they reveal the ways in which Europeans imagine themselves in relation to particular 'others', and illustrate the shifting boundaries of Europe and the European. 'Nina' in Extract 1 appears to be totally bemused by the desire of the woman she employs for one day off a week, feeling this desire to be unreasonable and indeed unfeeling. Having already told Anderson that employing migrant domestic workers is 'the Greek way to help foreigners' (Anderson, 2003: 
110), 'Nina' continues to narrate the relation between employer and employee in terms of affects and charitable disposition and in the process internally differentiates among states in the land mass of Europe. And it is precisely the capacity for universal feeling and humanism that is claimed as essentially European. Thus, she locates the division between herself as Greek employer and Bulgarian employee in the register of the emotions - 'there is no feeling for what I offer'. Greek 'us' is capable of feeling and empathy, entering the world of the other in the spirit of universal humanity, Bulgarian 'other' not so, and thus particularized outside the bounds of the universal. What might she (Nina) do if she heard the feeling of Nina Simone's 'Pirate Jenny' echoed in the voice of her employee?

Extract 2 shifts the attention to the male European child in preindependence Java but resonates with the constructed echo of the European as the subject whose capacity for emotional connection disrupts the division between 'us' and 'them'. I want it to be clear that I am not suggesting that deep emotional connection cannot develop between people whose structural relation is one of inequality and oppression/ exploitation - especially in circumstances where daily and intimate proximity is a feature of that relation. I am saying that the issue of emotional connection is also bound up with imaginaries of Europe and the European. Thus 'Nina's' national imaginary of 'the Greek way' and Nieuwenhuys's colonial desire echo one of the filaments running through constructions of Europe and the European in a way that suture their constructs into the hegemonic imaginary of Europe.

Domestic relations and desires are the site for the evocation of 'self' /'other' in these brief quotations and they repeat a mode of thought rooted in colonial discourse. They also inscribe a contradictory relation among nation-states of Europe in that they both speak their unity and specificity, while differentiating, in a hierarchical way, among different nations within the European land mass and between Europeans and those peoples whom they colonized.

This poses feminists with a number of questions that extend beyond the gendered relations of care work in a globalized world. Questions that I think we can begin to name by returning to the idea of the global care chain. Hochschild (2000: 131) introduced the concept as one marked by 'a series of personal links between people across the globe based on the paid or unpaid work of caring'. As Yeates (2003: 6) has pointed out, in doing so she and other feminists have shown how the internationalization of households and domestic services 'link[s] countries of different levels of "development"'. This draws attention to 'the domestic' not just as integral to processes of contemporary globalization but also as a category that links two different scales, that of household and that of nation.

Yet I am concerned that the global care chain, as a way of structuring 
international household relations, is thought of as an entirely new, as opposed to reconfigured, formation of the domestic, since long is the history of the multiracial, multinational division of household labour in terms of care, emotional work and childrearing. Settler colonialism ensured that. Additionally, to conceptualize it as a phenomenon linked only to the contemporary forms of global interconnection and inequality suggests that something becomes new and singular when such multinational/ethnic organization of household labour occurs in 'the west'. It suggests (again) that it is only in the west that 'domestic' encounters across ethnicity can occur, only when 'the European' (and in this case 'Euro-American' too) meets the migrant on the soil of Europe and/or North America that there is something we can call global about the divisions of household labour and intimacy. ${ }^{4}$ It suggests not only that globalized formation of household and domestic labour is new but also that it is qualitatively distinct when it is the 'hired-hand', rather than her employer, who has travelled the globe and begun a chain formation of ethnically differentiated femininities around which household labours and economies of gender are organized. This erases the centrality accorded domestic relations and practices in the European colonial project and by extension how despotic racialized technologies of gender were as central to the development of an elitist imaginary of Europe as was the development of the nation-state and parliamentary forms of government.

In this sense, the lessons offered by postcolonial feminist historians need wider circulation among feminist scholars working in other disciplines so that we might clarify theoretically exactly what it is that is different in the lived present. It seems to me that only by doing so will we be able to dislodge further two tropes running through imaginaries of Europe and the conceptions of gender that they underscore. First is the idea that the 'story' of the world - especially its moments of discontinuity and reconfiguration - is always and only driven by the lived experiences and/or ideological, political, social or economic concerns of 'EuroAmerica' and its formations: to write the world, that is, as a story of 'civilization' in which 'civilization' is always already reducible to 'Europe' and the 'European'.

Second is the idea that gender is an identity and practice of relations between women/men or femininity/masculinity and therefore to implicitly accord femininity and womanhood to only some women. One form this takes in the global care chains literature is to suggest that women able to afford to hire domestic workers are able to avoid gender conflict in the household. ${ }^{5}$ As if the classed and racialized conflicts between women employers and women employees, recorded by feminist researchers, are not a conflict of gender - or at least of the livedness of differently positioned femininities in a context of racialization and unequal exchange. In this Sojourner Truth (1851) may well have been speaking for migrant women 
domestic workers of diverse nationality and ethnicity when she asked, 'Ain't I a Woman?'

\section{ECONOMIES OF POWER}

When played on the cello, the 'Prelude' to J.S. Bach's six cello suites begins an invitation to the listener to venture within and explore the terrain of their internal world. In the transcription for saxophone by Japanese musician Yasuaki Shimizu (1996) the emphasis seems to be on the echo and there is a quality of throwing back the utterance to the utterer so that she might face and perhaps reconfigure her self-image.

Embedded as they are in the networks created by the capillaries of fractured belonging that the diverse populations of migrants and their descendants bring to the diasporic spaces (Brah, 1996) of contemporary Europe, cultural artefacts of numerous diasporic artists across the creative industries capture something of the multiple and competing social imaginaries that criss-cross the European geographical and social terrain. In a sense, they act in ways similar to Haraway's cyborgs, who, in their unfaithfulness to their origins, distil the 'potent fusions, and dangerous possibilities which progressive people' (Haraway, 1985) need if the hegemonic imaginary of Europe is to be challenged.

If, however, the visual and aural productions of those working in the cultural industries confound predominant interpretations of the past and the present, 'east' and 'west' and, indeed, the struggles over the meanings we attribute to different femininities (and their relation to class, ethnicity, sexuality), the visions offered by such cultural artefacts are resisted and/or ignored in unlikely as well as likely fields of scholarship.

Thus despite the very different political projects underlying feminist scholarship on the formation and effects of global care chains and EU attempts to construct an identity and constituency of Europeanness, these projects converge in some key areas. One area that is common to both the European and feminist imaginaries is that when considering the reorderings of space wrought by contemporary forms of globalization, their technologies of gender, race, ethnicity and religion occlude, ignore or disavow the history of Europe's racialized relations of rule with its intolerances, despotisms and forms of global interconnection that established crossnational links between households. Thus they reinscribe epistemologies that police both subaltern histories of earlier forms of global care chains and struggles over the meaning of contemporary respatializations of the European. They also meet when interrogated for the racialized presences and absences they explicitly or implicitly evoke in their depictions of the 'domestic' spaces of households and nations.

The following two questions allow brief consideration of the ways in 
which the scale of 'the domestic' is in play in both the imaginaries I have been discussing. First: 'What degrees of correspondence are there between a notion of the domestic/home as household, in which a primary task is the legitimate organization of intimate/sexual relations and the production (and reproduction) of self; and a notion of the domestic/home as the site of the nation(al) in which the specificity and reproduction of the nation(al) is dependent upon racialized, gendered and elitist myths of origin?' Second: 'In what ways, if at all, are colonial modes of knowing evoked and deployed as the unseen epistemological framework underwriting ideas about social inclusion in Europe and aspects of global care chain analysis?'

To begin to answer the first question would involve thinking about how fictions of both the household and those of the (European) nation(al) (as birthplace of civilization and of freedom) are premised upon a presumed ordering of gender relations in which a degree of communication between women and men is unparalleled elsewhere, and, a process of forgetting all that speaks against the myth of national origin. In addressing the second question, attention is given to the ways in which colonial discourse produced (a particular) Man (read European man) as the subject of history and in its wake positioned different groups of 'others' in a hierarchy of time/space relations along the axes 'modern/traditional', 'here/there'.

It is in this framework, then, that the scale of the domestic/home assumes its connotative power and we see how the term constructs a field of scalar units in which sexuality, gender, ethnicity and myth all converge to demarcate the shifting boundaries between different spaces of the domestic in which practices in one (household) determine belonging or not in the other (supra/national). And so the fate of the figures of the immigrant woman and the actually existing global care worker is to become the symbolic and embodied representatives of what Chandra Talpade Mohanty and Biddy Martin (2003: 90) referred to as the modality of 'not-being at home' and thus 'realising that home [is] an illusion of coherence and safety based on the exclusion of specific histories of oppression and resistance'.

Resolution of the dis-ease caused by such a realization will not, in my view, come from the violence of an imposed - and illusory - unity around fantasies of essential European goodness, the surrender of differences to a notion of higher principles, or even to a political project that seeks a degree of global justice but forgets history and holds in place a colonial teleology of woman's condition, experience and victimhood. Movement away from this unfortunate complicity in epistemological domination involves paying attention to history (in the sense of earlier forms of global interconnection, inequality and epistemological privilege), and the conceptualization of scale (and the way this orders relations between regions and peoples unequally) that is contained in the EU and feminist 
imaginary. Without this it will not be possible to decipher the connections between particular imaginaries of Europe, the conceptions of gender and gender relations they normalize or minoritize and how both of these reinscribe radical difference grounded in race and thus preclude the claim I am woman/black/Muslim/European.

\section{NOTES}

1. This article was originally written as a keynote address at the Fifth European Feminist Conference held at the University of Lund, Sweden in 2003. It has also been presented at Clark University, Worcester, Massachusetts and at the University of Syracuse, Syracuse, New York. I thank participants at each of these events for their comments. At these presentations, I was able to show images taken from magazine advertisements, the Internet and the work of the artist Sunil Gupta while also playing small clips of pieces of music, some of which are mentioned in the text. I have given the references to these pieces at the end of the article and would urge readers to try to hear them in the hope that something of what they add to the argument comes through. I would like to thank the anonymous referees for the comments, the editors of EJWS and Catherine Hall.

2. At Europa website: Europa.Eu.int/abc/symbols/anthem/index_en.htm

3. See note 2 .

4. Indeed Lutz (2002: 90), in an article that denies any easy categorization of things as either 'old' or 'new' has noted that global care chains do not announce a new category of difference among women but just that they constitute a new spatial arrangement for that encounter across difference.

5. 'Wrigley's analysis ... follows on Hochschild's book because it turns out that a third way of resolving that gender conflict, particularly in highincome two career families, is to employ a nanny. That's the best way to both save the marriage and let men off the hook and the workplace off the hook too' (Cerullo, n.d.).

\section{REFERENCES}

Anderson, Bridget (2000) Doing Dirty Work? The Global Politics of Domestic Labour. London: Zed Books.

Anderson, Bridget (2003) 'Just Another Job? The Commodification of Domestic Labour', pp. 104-14 in Barbara Ehrenreich and Arlie Russell Hochschild (eds) Global Woman: Nannies, Maids and Sex Workers in the New Economy. London: Penguin.

Balibar, Etienne (1991) 'Racism and Nationalism', pp. 37-67 in E. Balibar and Immanuel Wallerstein (eds) Race, Nation, Class: Ambiguous Identities. London: Verso.

Beethoven, Luwig van (1824) 'Ode to Joy', Symphony number Nine. Deutscher Grammophon.

Brah, Avtar (1996) Cartographies of Diaspora. London: Routledge.

Cerullo, Margaret (n.d.) 'Introducing Latinas into an Introductory Feminist Studies Course'; at: womencrossing.org/cerullo.hml (accessed 26 October 2005). 
Commission of the European Communities (2000) Shaping the New Europe. Brussels: Commission of the European Communities.

Haraway, Donna (1985) 'Cyborg Manifesto and Fractured Identities', Socialist Review 80: 65-108.

Hochschild, Arlie Russell (2000) 'The Nanny Chain', The American Prospect 11(4): 32-6.

Kofman, Elenore, Annie Phizacklea, Parvati Raghuram and Rosemary Sales (2000) Gender and International Migration in Europe: Employment, Welfare and Politics. London: Routledge.

Kristeva, Julia (1993) Nations without Nationalism. New York: Columbia University Press. (Orig. pub. Lettre Ouverte a Harlem Desir, Edition Rivages, 1990.)

Lewis, Gail and Sarah Neal (2005) 'Contemporary Political Contexts, Changing Terrains and Revisited Discourses', Ethnic and Racial Studies 28(3): 423-44.

Lutz, Helma (2002) 'At Your Service Madam! The Globalization of Domestic Space', Feminist Review 70: 89-103.

Mohanty, Chandra Talpade and Biddy Martin (2003) 'What's Home Got to Do with It?', in Chandra Talpade Mohanty (ed.) Feminism Without Borders: Decolonizing Theory, Practicing Solidarity. Durham, NC: Duke University Press. (Orig. pub. 1986.)

Moruzzi, Norma Claire (1994) 'A Problem with Headscarves: Contemporary Complexities of Political and Social Identity', Political Theory November: 653-72.

Mosher, M. (1994) 'The Judgemental Gaze of European Women: Gender, Sexuality and the Critique of Republican Rule', Political Theory 22(1): 25-44.

Nieuwenhuys, Robert (1995) Autobiography of a Javanese Childhood. Amsterdam: Huis Clos.

Parrenas, Rhacel Salazar (2001) Servants of Globalization: Women, Migration and Domestic Work. Stanford, CA: Stanford University Press.

Said, Edward (1993) Culture and Imperialism, London: Chatto and Windus.

Shimizu, Yasuaki (1996) 'Prelude', Cello Suites. Tokyo: The Far Side Music.

Simone, Nina (1964) 'Pirate Jenny', Nina Simone in Concert. New York: Phillips Label.

Stoler, Ann Laura (2002) Carnal Knowledge and Imperial Power: Race and the Intimate in Colonial Rule. Berkeley: University of California Press.

Truth, Sojourner (1851) 'Ain't I A Woman?', speech delivered to the Women's Convention, Akron, $\mathrm{OH}$.

Yeates, Nicola (2003) 'A Dialogue with "Global Care Chain" Analysis: Nurse Migration in the Irish Context', paper presented at the Social Policy Association Annual Conference, Teeside, UK, July.

Gail Lewis is Reader in Gender and Ethnicity, Institute for Women's Studies, Lancaster University. Her publications include 'Race', Gender, Social Welfare: Encounters in a Postcolonial Society (Polity Press, 2000), 'Racialising Culture is Ordinary', in Elizabeth Silva and Tony Bennett (eds) Contemporary Culture and Everyday Life (Sociology Press, 2003) and 'Welcome to the Margins: Diversity, Tolerance and Policies of Exclusion' in a special issue of Ethnic and Racial Studies 28(3), 2005, co-edited with Sarah Neal. She has worked on Feminist Review and is currently on the editorial team of Feminist Theory. Address: Institute of Women's Studies, University of Lancaster, Lancaster, LA1 4YL, UK. [email: g.a.lewis@ lancaster.ac.uk] 